\title{
Isolation, Identification and Partial Optimization of Novel Xylanolytic Bacterial Isolates from Bhilai-Durg Region, Chhattisgarh, India
}

\author{
Vasamsetty Shanthi*; Marthoor George Roymon \\ Department of Microbiology, St. Thomas College, Bhilai, Chhattisgarh, India

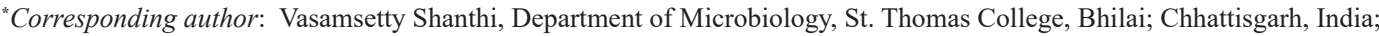 \\ Tel.: +91-9406103610, E-mail: shanti_162@rediffmail.com
}

Received: 30 Aug. 2015; $\quad$ Revised: 5 Sep. 2017; Accepted: 16 Sep. 2017; Published online: 11 Aug. 2018

\begin{abstract}
Background: Plant biomass and agricultural waste products disposal is a serious problem in agriculture based countries. These wastes, usually rich in xylan can be satisfactorily converted to industrially important and useful products by efficient biotechnological application of potent xylanase producing bacteria which generally have high temperature and $\mathrm{pH}$ optima. Objective: The aim was to isolate and identify xylanolytic bacterial isolates from Bhilai-Durg region of Chhattisgarh, India which was otherwise unexplored for isolation of thermoalkalophilic xylanase producing bacteria. Partial scale up of process development was performed.

Materials and Methods: Xyalanse producing bacteria were isolated from probable samples following three stages of screening procedures. The potent isolates were identified and various parameters affecting xylanase production were optimized using the conventional one-factor-at-a-time approach.

Results: Two potent indigenous bacterial isolates belonged to genus Bacillus and designated as Bacillus sp. MCC2728 and Bacillus sp. MCC2727 were isolated from forest soils with the ability to degrade xylan. Significant differences were observed in their morphology and phenotypic characters amongst themselves and with its closest type strains implying the novelty of the two isolates. After optimization, maximum xylanase levels were obtained at $\mathrm{pH} 9.0,55^{\circ} \mathrm{C}$ for Bacillus $s p$. MCC2728 and $50^{\circ} \mathrm{C}$ for Bacillus sp. MCC2727, 5\% inoculum, agitation speed (150 rpm). Yeast extract and peptone are best nitrogen sources and wheat bran, the best carbon source. The GenBank/EMBL/DDBJ accession numbers of strains Bacillus sp. MCC2728 and Bacillus sp. MCC2727 are KP742971 and KT444621 respectively. Wheat bran, Yeast extract and peptone proved to be the best carbon and nitrogen sources respectively and xylose as an additive was found to be contributing to maximize the xylanase yields.

Conclusion: Two potent thermoalkalophilic novel bacterial isolates were successfully isolated with xylan degrading ability which may be used as promising xylanase producing candidates for various industrial purposes using agricultural based waste residues.

Keywords: Bacillus sp., Optimization, Phylogenetic analysis, Thermoalkalophilic bacteria, Xylanase.
\end{abstract}

\section{Background}

Hemicelluloses are considered as the second most abundant polysaccharide in nature after cellulose, which represents $20-35 \%$ of plant biomass on earth. The most common hemicelluloses found in plants and trees are xylan (1). This common hemicellulosic polysaccharide is distributed in many types of tissues and cells in a variety of plant species but found abundantly in woody and annual plants (2). In case of cell walls of land plants, xylan represents about $30 \%$ of dry weight in hardwoods from angiosperms and about $12 \%$ of dry weight in softwoods from gymnosperms (3). Xylan being one of the abundant materials in plant biomass is also found in solid agricultural and agro industrial residues (4) which can be potentially used to produce various industrially useful products like biofuels, animal feed, enzymes etc. (5). Xylan has many uses in industries such as production of numerous value added products (6). Moreover, the ever growing human population has propelled mankind to use

Copyright (C 2017 The Author(s); Published by National Institute of Genetic Engineering and Biotechnology. This is an open access article, distributed under the terms of the Creative Commons Attribution-NonCommercial 4.0 International License (http://creativecommons.org/licenses/ by-nc/4.0/) which permits others to copy and redistribute material just in noncommercial usages, provided the original work is properly cited. 
advanced agricultural practices thereby enhancing crop production and yield. This increased demand of food crops has resulted in problems related to proper disposal of agricultural waste residues leading to pollution. The existence of such pollution problems has encouraged their utilization for various bioconversion processes and production of many industrially useful products. The efficient use of plant biomass particularly nonfood lignocellulosic material as renewable resource for efficient biotechnological applications has become increasingly important in recent years (7). Looking at the present global scenario; the main aim is to find enzymes that can be integrated into industrial processes for converting biomass into valuable products. A distinct class of enzymes produced by microorganisms is xylanases. These enzymes have incurred a lot of interest in the recent times, as the substrate, xylan is of special interest as a renewable resource. It is a large component of agricultural wastes and thus can be used as a source of biomass (8). Xylanases have created a niche for themselves in the field of enzyme technology due to having an biotechnological applications. Although fungi have incurred a great interest as potent xylanase producers, but the simple nutritional requirements, high growth rate, less generation time, high temperature and $\mathrm{pH}$ optima, negligible cellulase activities, considerably good levels of xylanase and low protein purification costs make bacterial xylanases the preferred choice for various industrial processes (9).

\section{Objective}

The state of Chhattisgarh, India is known for its rich resources and biosphere which is endowed with thick and diverse vegetation. Its many virgin forests which are yet to be explored make it a biodiversity hotspot. A study was undertaken to explore industrially important xylanase producing bacteria from the rich natural resources of Bhilai- Durg region of Chhattisgarh, India as there are no published reports till date on isolation and screening of xylanolytic bacterial isolates from this region.

\section{Materials and Methods}

\subsection{Sample Collection}

Different types of samples including forest soil, dung, decaying wood and lignocellulosic material were collected from different areas of Bhilai-Durg region of Chhattisgarh state, India and immediately transferred to the sterile containers and stored at $4{ }^{\circ} \mathrm{C}$ till further use.

\subsection{Isolation and Screening}

One gram of each of the collected samples were suspended in $10 \mathrm{~mL}$ of sterile distilled water and serially diluted till $10^{-5}$ dilution. $0.1 \mathrm{~mL}$ of the highest dilution was then spread plated on hemicellulose rich; wheat bran agar medium [5\% (w/v) wheat bran, $0.5 \%$ $(\mathrm{w} / \mathrm{v})$ peptone, $0.5 \%(\mathrm{w} / \mathrm{v}) \mathrm{NaCl}, 0.3 \%(\mathrm{w} / \mathrm{v})$ yeast extract and $1.5 \%(\mathrm{w} / \mathrm{v})$ agar] for the enriched growth of hemicellulose utilizing bacterial isolates by incubating for 3 days (10). Unless specified the sterilization steps were performed at $121^{\circ} \mathrm{C}\left(15 \mathrm{lb}_{\text {.inch }}{ }^{-2}\right)$ for 20 minutes. The $\mathrm{pH}$ of the sterilized medium was adjusted to 9.0 with sterile $10 \% \mathrm{Na}_{2} \mathrm{CO}_{3}$ solution and incubation temperature maintained at $50{ }^{\circ} \mathrm{C}$ to encourage thermoalkalophilic bacterial isolates. Bacterial isolates obtained in this preliminary screening step were sub-cultured to purity and each of the isolates were then spot inoculated on xylan agar medium $[0.5 \%(\mathrm{w} / \mathrm{v})$ Birch wood xylan, $0.5 \%(\mathrm{w} / \mathrm{v})$ Yeast extract, $0.5 \%(\mathrm{w} / \mathrm{v})$ Peptone, 0.02 $\%(\mathrm{w} / \mathrm{v}) \mathrm{MgSO}_{4} .7 \mathrm{H}_{2} \mathrm{O}, 0.1 \%(\mathrm{w} / \mathrm{v}) \mathrm{K}_{2} \mathrm{HPO}_{4}$ and $2.0 \%$ $(\mathrm{w} / \mathrm{v})$ agar] for qualitative screening of the isolates as a part of secondary screening step (11). Their ability to produce extracellular xylanase was detected by Congo red plate assay method.

\subsection{Congo Red Assay}

The plates after an incubation period of 3 days were placed in 1\% Congo red solution and kept for 10-15 minutes and destained with $1 \mathrm{M} \mathrm{NaCl}$ solution for visibility of hydrolytic clearance zone (12).

\subsection{Xylanase Production}

In the final process of screening, the selected isolates were subjected to submerged fermentation for determining their potential for maximum xylanase production as part of quantitative screening by growing in liquid xylan medium with same composition as xylan agar medium except agar. Twenty $\mathrm{mL}$ of liquid xylan medium was inoculated with $1 \% \mathrm{v} / \mathrm{v}$ of 18 hour old fresh culture and incubated for 3 days at 50 ${ }^{\circ} \mathrm{C}$ on a rotary shaker (Rivotek, India) at $150 \mathrm{rpm}$. On completion of incubation period, the production medium was processed for xylanase enzyme extraction (13).

\subsection{Preparation of Inoculum}

The inoculum for final screening procedure and for further enzyme production studies was raised by inoculating a loop full of 18 hour old pure culture of the bacterial isolates in $50 \mathrm{~mL}$ of xylan liquid medium in $250 \mathrm{~mL}$ Erlenmeyer flask and incubating for 3 days at temperatures $\left(37 \pm 2{ }^{\circ} \mathrm{C}\right)$.

\subsection{Xylanase Extraction}

The bacterial isolates selected through screening 
procedures were used for the production of xylanase enzyme under the conditions already mentioned. Cell free extract was obtained by centrifugation (REMI C-24BL, Cooling centrifuge; India) at $10,000 \times \mathrm{g}$ for 10 min at $4{ }^{\circ} \mathrm{C}$. The supernatant obtained was used as a source of crude extracellular xylanase enzyme (10) for various analytical purposes.

\subsection{Xylanase Assay}

The quantity of xylanase enzyme produced by each of the isolate in liquid xylan medium was determined following the method of Bailey et al. (1992) with some modifications (14). $1.0 \%$ Birch wood xylan (HiMedia, India) in $50 \mathrm{mM}$ Glycine-NaOH buffer ( $\mathrm{pH}$ 9.2) was used as substrate. $0.5 \mathrm{~mL}$ buffered substrate was reacted with $0.5 \mathrm{~mL}$ of suitably diluted crude xylanase enzyme at $55{ }^{\circ} \mathrm{C}$. The reaction was terminated after $10 \mathrm{~min}$ by adding $3 \mathrm{~mL}$ DNS reagent (15) and boiled for 5 minutes. After cooling, the released xylose was quantified at $540 \mathrm{~nm}$ against reagent blank which was prepared in the same manner except that $0.5 \mathrm{~mL}$ buffer replaced the crude enzyme. An enzyme blank was also set up in the pattern in which the reagent was added prior to the addition of crude so that only the released reducing sugar is estimated. A standard of xylose (HiMedia, India) was prepared using stock concentration of 10 g. $\mathrm{L}^{-1}$. One unit of xylanase activity was defined as $1 \mu \mathrm{mol}$ of xylose liberated per minute per $\mathrm{mL}$ of enzyme preparation under standard assay conditions.

\subsection{Total Soluble Protein Estimation}

Total soluble protein was estimated by Lowry's method (16) using Bovine serum albumin as standard (stock concentration- $1 \mathrm{mg} \cdot \mathrm{mL}^{-1}$ ).

\subsection{Identification of Bacterial Isolates}

Phenotypic and molecular characterization was carried out to enable the identification of the selected bacterial isolates. The pure cultures of potent bacterial isolates screened out through the three screening procedures were sent to National center for cell science (NCCS, Pune, Maharashtra, India) for identification purpose.

3.10. Phylogenetic Analysis

The 16s rRNA sequences of the isolates were aligned with closest type strains in the database to ascertain the phylogenetic position of the isolated strains using phylogeny construction by Neighbor-joining method (17) and Kimura two-parameter model (18) was used to compute the evolutionary distances. Boot-strap phylogeny method taking 1000 replicates into account was used to analyze the phylogenetic tree for the stability among the clades (19).

\subsection{Optimization Studies}

The different parameters probably contributing to the increase in xylanase production like medium $\mathrm{pH}$ (7-12 with an increment of $1.0 \mathrm{pH}$ unit), inoculum size $(0.5 \%$, $1 \%, 2 \%, 5 \%$ and $10 \%)$, incubation temperature (40$80{ }^{\circ} \mathrm{C}$ with $5^{\circ} \mathrm{C}$ increment), agitation rate $(50 \mathrm{rpm}$ to $250 \mathrm{rpm}$ with an increment of $50 \mathrm{rpm}$ ) best carbon and nitrogen source were evaluated. All the optimization studies were performed using the conventional onefactor-at-a-time approach wherein only one factor was varied at a time keeping all others at a constant level.

\subsection{Statistical Analysis}

All the observations are mean of three experimental replicates. The descriptive statistics of the observations are represented as mean \pm standard deviation. In order to find the relationship between the clearance zone diameter and the enzyme activity, Bivariate correlation was to determine Karl Pearson's coefficient of correlation (r). Linear regression analysis was performed to determine the correlation between the independent variable (zone diameter with that of dependent variable (enzyme activity). The $p$-value < 0.05 was considered statistically significant. The SPSS (version 16.0) statistical program was used for the analysis.

\section{Results}

\subsection{Isolation and Screening}

Isolation of xylanase producing bacteria from various probable samples (soil, dung, decaying wood and decomposed lignocellolosic material) were collected from Bhilai-Durg region of Chhattisgarh state, India. In total 177 bacterial isolates were collected, mostly from soil samples of forest and dense plantation areas. On qualitative screening on xylan agar medium using Congo red assay method, 24 bacterial isolates were selected on the basis of the clearance zone formation for the final screening process. All the 24 isolates produced a significant amount of extracellular xylanase when grown in liquid xylan medium under submerged conditions (Table 1). In order to find out if any correlation existed between the zone diameter and the enzyme activity, correlation and regression analysis was done. Bivariate correlation analysis was performed by Pearson correlation using quantitative variables, the results of which are summarized in Table 2.

The value of $r=0.131(p<0.05)$ indicates that there is a downhill or negative relationship between zone diameter and the corresponding xylanase activity. The scatter plot (Fig. 1) of enzyme activity with respect to 
zone diameter reveals no correlation between the factors. The significance (2-tailed) value of 0.551 indicates that there is no statistically significant correlation between the clearance zone diameter and the corresponding enzyme activity. The regression value $(\mathrm{R}=0.126)$ indicates a very low degree of correlation between zone diameter and xylanase activity. On the basis of secondary and final screening process; two bacterial isolates designated as IS1-03 and ISL-58 were selected for further identification studies.

\subsection{Identification of Potent Cultures}

The bacterial isolates exhibiting significant hydrolytic zone and maximum xylanolytic activity indicated by xylanase assay in the final screening procedure were obtained. This study reports the isolation of two novel thermoalkalophilic bacterial isolates possessing xylanlolytic ability. Both the strains show aerobic growth, round, cream coloured colonies when grown on nutrient agar medium at $37^{\circ} \mathrm{C}$ and are flat with no elevation. Both ISL-03 and ISL-58 show gram positive nature. ISL-03 and ISL-58 both are endospore formers but differ in spore position. Both are motile but ISL58 is sluggishly motile. Both are catalase positive and can grow at $\mathrm{pH}$ 9.0. The data related to morphological, phenotypic and biochemical characters of ISL-03 and ISL-58 indicate that the two xylanolytic bacterial strains are the members of genus Bacillus (Table 3).

\subsection{Phylogenetic Analysis}

The evolutionary relationship of strain ISL-03 and ISL-58 with the closely related taxa was inferred using the Neighbour-joining method using MEGA5. The partial nucleotide sequence of the 16S rRNA gene

Table 1. Summary of secondary and final screening for xylanolytic bacteria. Two novel thermoalkalophilic bacterial isolates possessing xylanolytic ability are indicated as bold.

\begin{tabular}{|c|c|c|c|c|c|c|}
\hline \multirow{2}{*}{$\mathbf{S} / \mathbf{N}$} & \multirow{2}{*}{$\begin{array}{l}\text { Isolate } \\
\text { identity }\end{array}$} & \multirow{2}{*}{$\begin{array}{c}\text { Qualitative } \\
\text { assay } \\
\text { Zone Diameter } \\
\text { (cm) }\end{array}$} & \multicolumn{4}{|c|}{ Quantitative assay } \\
\hline & & & $\begin{array}{c}\text { Xylanase Activity } \\
\text { (IU.mg }\end{array}$ & $\begin{array}{c}\text { Cellulase Activity } \\
\left.\text { (IU.mg }{ }^{-1}\right)\end{array}$ & $\begin{array}{c}\text { Total Protein } \\
\left.\text { Content (mg.mL } L^{-1}\right)\end{array}$ & $\begin{array}{c}\text { Specific Activity } \\
\text { (IU.mg-1) }\end{array}$ \\
\hline 1 & ISL-1 & 1.3 & $16.82 \pm 1.034$ & $4.88 \pm 1.53$ & $2.78 \pm 0.25$ & 6.050 \\
\hline 2 & ISL-3 & 1.6 & $36.61 \pm 3.866$ & $1.48 \pm 0.67$ & $2.0 \pm 0.36$ & 18.30 \\
\hline 3 & ISL-6 & 1.9 & $8.85 \pm 1.221$ & $3.18 \pm 0.40$ & $1.83 \pm 0.38$ & 4.83 \\
\hline 4 & ISL-9 & 1.4 & $12.53 \pm 1.189$ & $2.33 \pm 0.28$ & $2.21 \pm 0.22$ & 5.66 \\
\hline 5 & ISL-10 & 1.2 & $21.45 \pm 1.808$ & $3.35 \pm 0.30$ & $2.43 \pm 0.20$ & 8.82 \\
\hline 6 & ISL-13 & 1.4 & $7.15 \pm 0.563$ & $4.65 \pm 0.73$ & $1.35 \pm 0.30$ & 5.29 \\
\hline 7 & ISL-16 & 1.1 & $13.84 \pm 3.668$ & $3.85 \pm 0.35$ & $2.05 \pm 0.08$ & 6.75 \\
\hline 8 & ISL-17 & 1.5 & $24.16 \pm 3.157$ & $2.81 \pm 0.40$ & $2.40 \pm 0.37$ & 10.06 \\
\hline 9 & ISL-19 & 1.9 & $14.02 \pm 2.190$ & $2.2 \pm 0.40$ & $2.18 \pm 0.16$ & 6.43 \\
\hline 10 & ISL23 & 1.3 & $22.47 \pm 1.028$ & $2.41 \pm 0.76$ & $1.61 \pm 0.17$ & 13.95 \\
\hline 11 & ISL25 & 1.4 & $8.44 \pm 1.752$ & $3.15 \pm 0.13$ & $1.43 \pm 0.36$ & 5.90 \\
\hline 12 & ISL-30 & 1.7 & $23.56 \pm 2.449$ & $2.33 \pm 0.38$ & $2.38 \pm 0.14$ & 13.68 \\
\hline 13 & ISL-35 & 1.2 & $19.35 \pm 2.177$ & $1.43 \pm 0.40$ & $2.48 \pm 0.17$ & 7.80 \\
\hline 14 & ISL-38 & 1.6 & $13.13 \pm 2.610$ & $3.05 \pm 1.23$ & $1.81 \pm 0.20$ & 7.25 \\
\hline 15 & ISL-41 & 1.2 & $15.76 \pm 0.525$ & $4.48 \pm 1.11$ & $2.71 \pm 0.10$ & 5.81 \\
\hline 16 & ISL-43 & 1.5 & $16.91 \pm 1.144$ & $3.55 \pm 0.56$ & $3.33 \pm 0.14$ & 5.07 \\
\hline 17 & ISL-44 & 1.6 & $10.87 \pm 1.488$ & $2.56 \pm 0.55$ & $3.01 \pm 0.17$ & 3.61 \\
\hline 18 & ISL-48 & 1.4 & $16.15 \pm 1.203$ & $1.66 \pm 0.57$ & $2.70 \pm 0.26$ & 5.98 \\
\hline 19 & ISL-50 & 1.0 & $18.25 \pm 1.145$ & $1.16 \pm 0.28$ & $2.65 \pm 0.20$ & 3.11 \\
\hline 20 & ISL-52 & 1.4 & $16.19 \pm 1.691$ & $2.08 \pm 0.14$ & $2.83 \pm 0.28$ & 5.72 \\
\hline 21 & ISL-55 & 1.2 & $14.15 \pm 1.693$ & $1.15 \pm 0.37$ & $2.73 \pm 0.24$ & 5.18 \\
\hline 22 & ISL-56 & 1.5 & $21.28 \pm 1.593$ & $1.38 \pm 0.20$ & $2.93 \pm 0.35$ & 7.26 \\
\hline 23 & ISL-58 & 1.8 & $33.96 \pm 2.059$ & $1.11 \pm 0.10$ & $2.25 \pm 0.27$ & 15.09 \\
\hline 24 & ISL-65 & 1.6 & $16.53 \pm 1.927$ & $2.40 \pm 0.37$ & $2.23 \pm 0.20$ & 7.41 \\
\hline
\end{tabular}


Table 2. ANOVA results for Correlation and Regression analysis.

\begin{tabular}{lccccc}
\hline Model & SS & df & MS & F & Sig $(p)$ \\
\hline Regression & 18.482 & 1 & 18.482 & 0.352 & $0.559^{\mathrm{A}}$ \\
Residual & 1154.901 & 23 & 52.496 & - & - \\
\hline
\end{tabular}

of ISL-03 strain displayed $99.75 \%$ sequence similarity with the available $16 \mathrm{~S}$ rRNA gene sequences of the type strains $B$. stratosphericus $41 \mathrm{KF}^{2} \mathrm{a}^{\mathrm{T}}$ (AJ831841), $B$. altitudinus $41 \mathrm{KF}^{2} \mathrm{~b}^{\mathrm{T}}$ (ASJC01000029) and $B$. aerophilus $28 \mathrm{~K}^{\mathrm{T}} \quad$ (AJ831844); 99.66\% similarity with B. xiamenensis $\mathrm{HYC}-10^{\mathrm{T}}$ (AMSH010000114) and $99.24 \%$ similarity with non type strain $B$. safensis FO-36b ${ }^{\mathrm{T}}$ (ASJD01000027). However, ISL58 revealed 99.86 to $99.79 \%$ sequence similarity with B.aerophilus, B. stratosphericus, B. altitudinis and $B$. xiamenensis. According to the Neighborjoining phylogentic tree, strain ISL-03 and ISL58 form a clade with B. xiamenensis, B.altitidinis, $B$. stratosphericus and $B$. aerophilus. Although $B$. aerophilus, B. stratosphericus, B. altitudinis, ISL03 and ISL-58 show $100 \%$ sequence similarity with one another but the morphological properties and phenotypic characteristics between the two novel isolates and with the closely related Bacillus sp. differ considerably, thus strongly recommending the novelty of the isolated strains. Therefore, ISL-03 and ISL-58 are being designated as Bacillus sp. MCC2728 (Fig. 2) and Bacillus sp. MCC2727 (Fig. 3) respectively. The 16S rRNA sequences of the two bacterial isolates have been submitted to GenBank. The GenBank/ EMBL/DDBJ accession numbers for the 16S rRNA

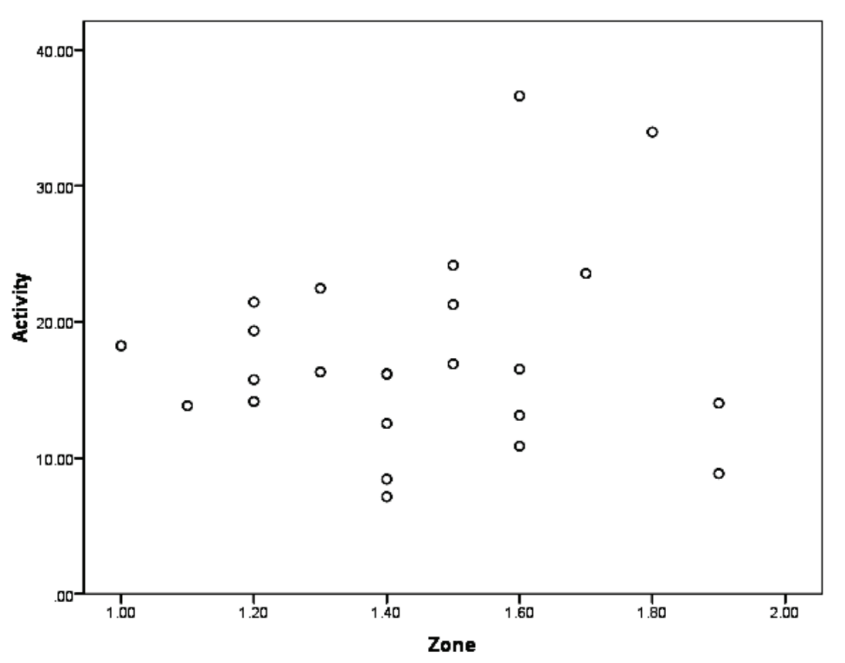

Figure 1. Scatter plot between Zone diameter and Xylanase activity. gene sequences of strains Bacillus sp. MCC2728 and Bacillus sp. MCC2727 are KP742971 and KT444621 respectively.

\subsection{Optimization of Various Parameters}

\subsection{1. $\mathrm{pH}$}

The study on the effect of initial medium $\mathrm{pH}$ on the production of xylanase by Bacillus sp. MCC2727 and Bacillus sp. MCC2728 was done in the range of $\mathrm{pH}$ 7-12. All the medium $\mathrm{pH}$ evaluated seemed to produce detectable amounts of enzyme activity. However, maximum titer of xylanase was attained by both Bacillus sp. MCC2728 (39.51 \pm 1.04 IU.mL $\left.{ }^{-1}\right)$ and Bacillus sp. MCC2727 (36.52 \pm 0.50 IU.mL $\left.{ }^{-1}\right)$ at $\mathrm{pH} 9.0$ after 72 and 60 hours of incubation period respectively (Fig. 4A). Xylanase productivity was maximum and consistent at $\mathrm{pH} 9.0$, while inconsistent and lower productivity was obtained at higher medium $\mathrm{pH}(\mathrm{pH} \mathrm{10,11}$ and 12).

\subsubsection{Incubation Temperature}

One of the important environmental factors which significantly affects the level of extracellular enzyme production is temperature. Optimum temperature for xylanase production by Bacillus sp. MCC 2727 and Bacillus sp. MCC2728 was evaluated at varying temperatures in the range of $40-80{ }^{\circ} \mathrm{C}$ with $5{ }^{\circ} \mathrm{C}$ increment. Maximum enzyme productivity was observed at $55{ }^{\circ} \mathrm{C}$ for Bacillus sp. MCC2728 and at $50{ }^{\circ} \mathrm{C}$ for Bacillus sp. MCC2727. Both Bacillus sp. MCC2727 and Bacillus sp. MCC2728 recorded negligible amounts of xylanase when incubated at 75 ${ }^{\circ} \mathrm{C}$ and no enzyme activity was detected at $80^{\circ} \mathrm{C}$ (Fig. 4B).

\subsubsection{Inoculum Size}

The influence of inoculum size on xylanase production by Bacillus sp. MCC2727 and Bacillus sp. MCC 2728 was assessed by altering the amount of inoculum added to the production medium. Although detectable amounts of xylanase production was observed with lower inoculum sizes but maximum enzyme activity was only recorded at 5\% inoculum (Fig. 4C) and enzyme activity dropped drastically at $10 \% \mathrm{v} / \mathrm{v}$ inoculum size.

\subsubsection{Shaking Conditions}

The influence of agitation on xylanase production was investigated at different rotating speeds (Fig. 4D). Maximum xylanase production was obtained at 150 rpm by both Bacillus sp. MCC2727 and Bacillus sp. MCC2728. Lower yields of xylanase were recorded at lower agitation speeds of $50 \mathrm{rpm}$ and $100 \mathrm{rpm}$. 
Shanthi V\& Roymon MG

Table 3. Phenotypic and biochemical characteristics that differentiate ISL-03 (Bacillus sp. MCC2728) and ISL-58 (Bacillus sp. MCC2727).

\begin{tabular}{|c|c|c|c|c|c|}
\hline Characteristic & & & solate Identity & & \\
\hline & 1 & 2 & 3 & 4 & 5 \\
\hline Size & $2-3 \mathrm{~mm}$ & $3-4 \mathrm{~mm}$ & $2-3 \mathrm{~mm}$ & $5-8 \mathrm{~mm}$ & $3-5 \mathrm{~mm}$ \\
\hline Shape & cream & Cream & white & white & white \\
\hline Margin & Wavy & Entire & regular & irregular & irregular \\
\hline Consistency & Translucent & Opaque & NA & NA & NA \\
\hline Elevation & Flat & Flat & convex & raised & raised \\
\hline Gram Nature & Gram positive rods & Gram positive thin rods & Gram positive rods & Gram positive rods & Gram positive rods \\
\hline Motility & Motile & Sluggishly motile & motile & motile & motile \\
\hline Spore position & Central round spore & Sub terminal ellipsoidal spore & NA & NA & NA \\
\hline Catalase & + & + & + & + & + \\
\hline Growth at: & & & & & \\
\hline pH 5.0 & - & - & + & - & - \\
\hline pH 9.0 & + & + & - & + & + \\
\hline $37^{\circ} \mathrm{C}$ & + & + & + & + & + \\
\hline $50^{\circ} \mathrm{C}$ & + & + & + & - & - \\
\hline Ribose & + & + & NA & + & + \\
\hline Fructose & + & + & NA & + & + \\
\hline Glucose & + & + & - & + & + \\
\hline Rhamnose & - & - & + & + & + \\
\hline Arabinose & - & - & + & + & + \\
\hline Galactose & - & - & NA & + & + \\
\hline Casein Hydrolysis & + & + & - & NA & NA \\
\hline DNAase & + & + & NA & NA & NA \\
\hline Starch & - & - & + & + & - \\
\hline Gelatin & - & - & + & NA & NA \\
\hline Lactose & - & - & NA & + & + \\
\hline Xylose & - & - & - & + & + \\
\hline Maltose & - & - & NA & + & + \\
\hline Raffinose & - & + & - & + & + \\
\hline Trehalose & + & + & + & + & - \\
\hline Melibiose & - & - & NA & + & + \\
\hline Sucrose & + & + & + & + & + \\
\hline Mannose & + & + & NA & + & + \\
\hline Inulin & - & - & + & + & + \\
\hline Sodium Gluconate & - & - & NA & NA & NA \\
\hline Glycerol & + & - & + & + & + \\
\hline Salicin & + & + & NA & NA & NA \\
\hline Dulcitol & - & - & + & - & + \\
\hline Inositol & - & - & + & - & + \\
\hline Sorbitol & - & + & + & + & - \\
\hline Mannitol & + & + & + & + & + \\
\hline Adonitol & - & - & NA & NA & NA \\
\hline Arabitol & - & - & NA & NA & NA \\
\hline Erythritol & - & - & NA & NA & NA \\
\hline$\alpha$-Methyl-D-Glucoside & - & - & NA & NA & NA \\
\hline Xylitol & WP & - & NA & + & - \\
\hline ONPG & - & - & + & + & + \\
\hline Aesculin hydrolysis & + & + & + & + & + \\
\hline Citrate Utilization & + & + & - & + & - \\
\hline Malonate Utilization & - & - & NA & NA & NA \\
\hline Sorbose & - & - & + & + & + \\
\hline Voges-Proskuer & - & - & - & + & + \\
\hline Nitrate Reduction & - & - & - & + & + \\
\hline Arginine & - & + & - & + & - \\
\hline Cellobiose & + & - & + & - & + \\
\hline Melezitose & - & - & NA & NA & NA \\
\hline$\alpha$-Methyl-D-Mannoside & - & - & NA & NA & NA \\
\hline
\end{tabular}

Strains: 1, Bacillus sp. MCC2728 (ISL-03); 2, Bacillus sp. MCC2727 (ISL-58); 3, Bacillus altitudinus 41KF2b ${ }^{\mathrm{T}}$; 4, Bacillus aerophilus $28 \mathrm{~K}^{\mathrm{T}}$; 5 , Bacillus stratosphericus $41 \mathrm{KF} 2 \mathrm{a}^{\mathrm{T}}+$, Positive; -, Negative; WP, Weakly positive; NA, Data not available. All the data of 3-5 have been derived from Shivaji et al. 2006 (31). 


\subsubsection{Carbon Source}

Different carbon sources including both simple and complex forms were evaluated for their ability to promote optimum levels of xylanase secretion. It is noteworthy to mention that wheat bran was found to support maximum xylanase production in both the bacterial strains (Table 4). The different lignocellulosic materials were capable to induce good amount of xylanase compared to soluble simple sugars. However, xylose; a simple sugar contradicted this finding by supporting significant levels of xylanase production.

\subsubsection{Nitrogen Source}

Various organic and inorganic nitrogen sources were screened to investigate as to which of them influences

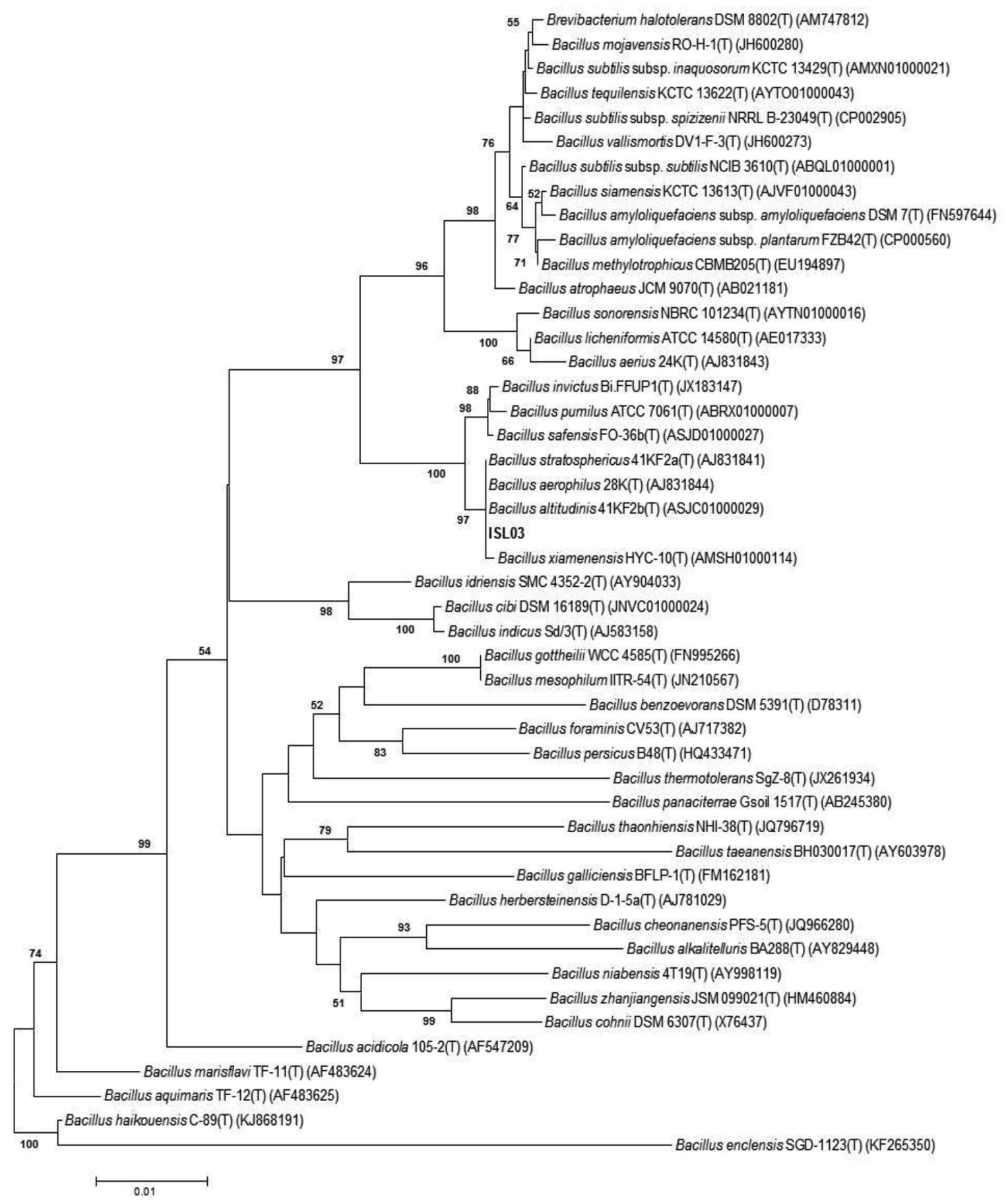

Figure 2. Phylogenetic analysis of ISL-03 (Bacillus sp. MCC 2728). 
the maximum xylanase production. Yeast extract and peptone individually served as efficient nitrogen sources for xylanase production in case of Bacillus sp. MCC2728. However the combined effect of yeast extract and peptone resulted in a noteworthy increase in xylanase activity (Table 5) but Bacillus sp. MCC2727 preferred yeast extract over other nitrogen sources. Inorganic forms of nitrogen proved inefficient in inducing xylanase production.

\section{Discussion}

\subsection{Isolation and Screening}

The isolation and screening of thermostable alkalophillic xylanase producing bacteria was performed in three stages from the various collected samples. Forest soil

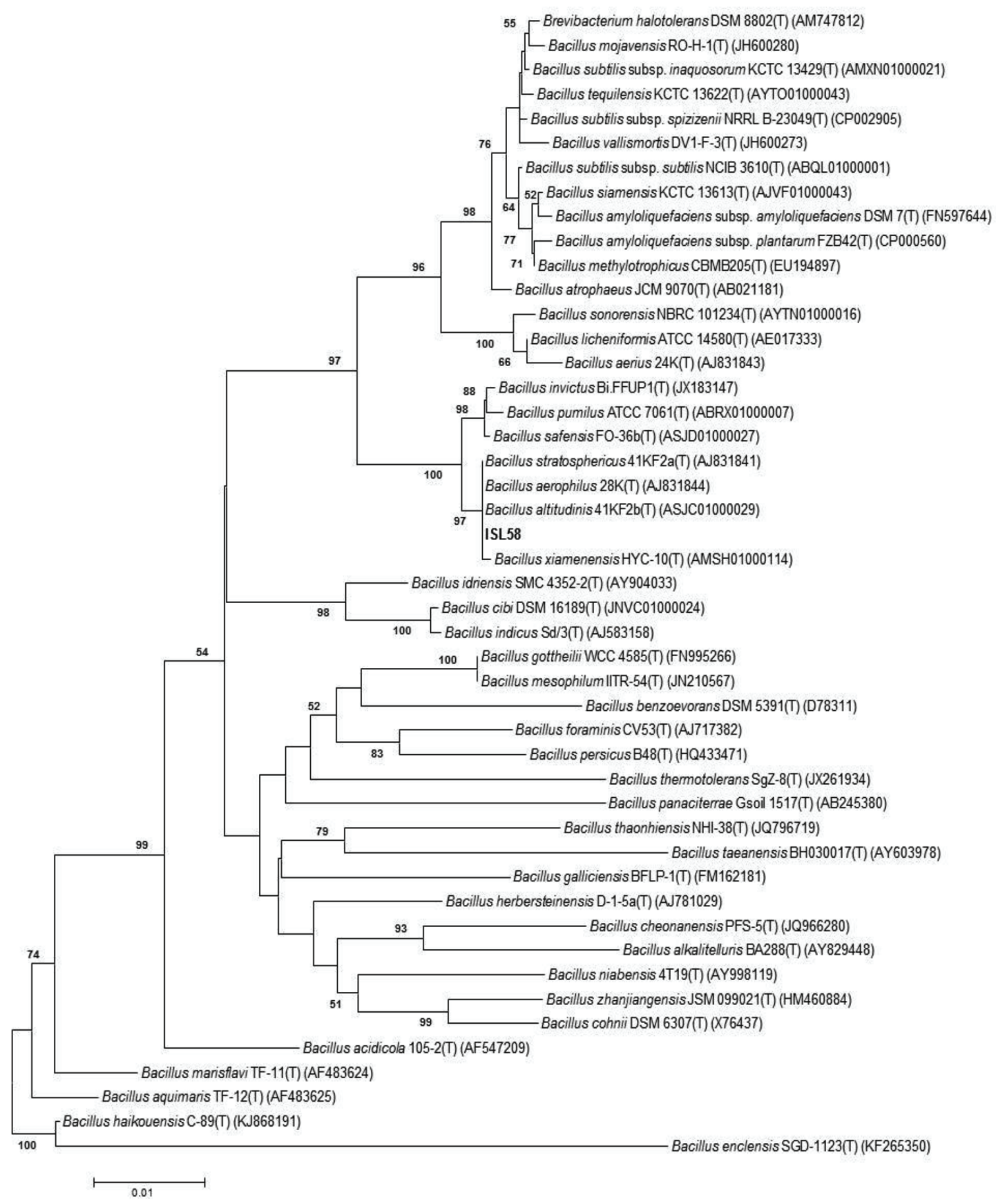

Figure 3. Phylogenetic tree of ISL-58 (Bacillus sp.MCC2727). 

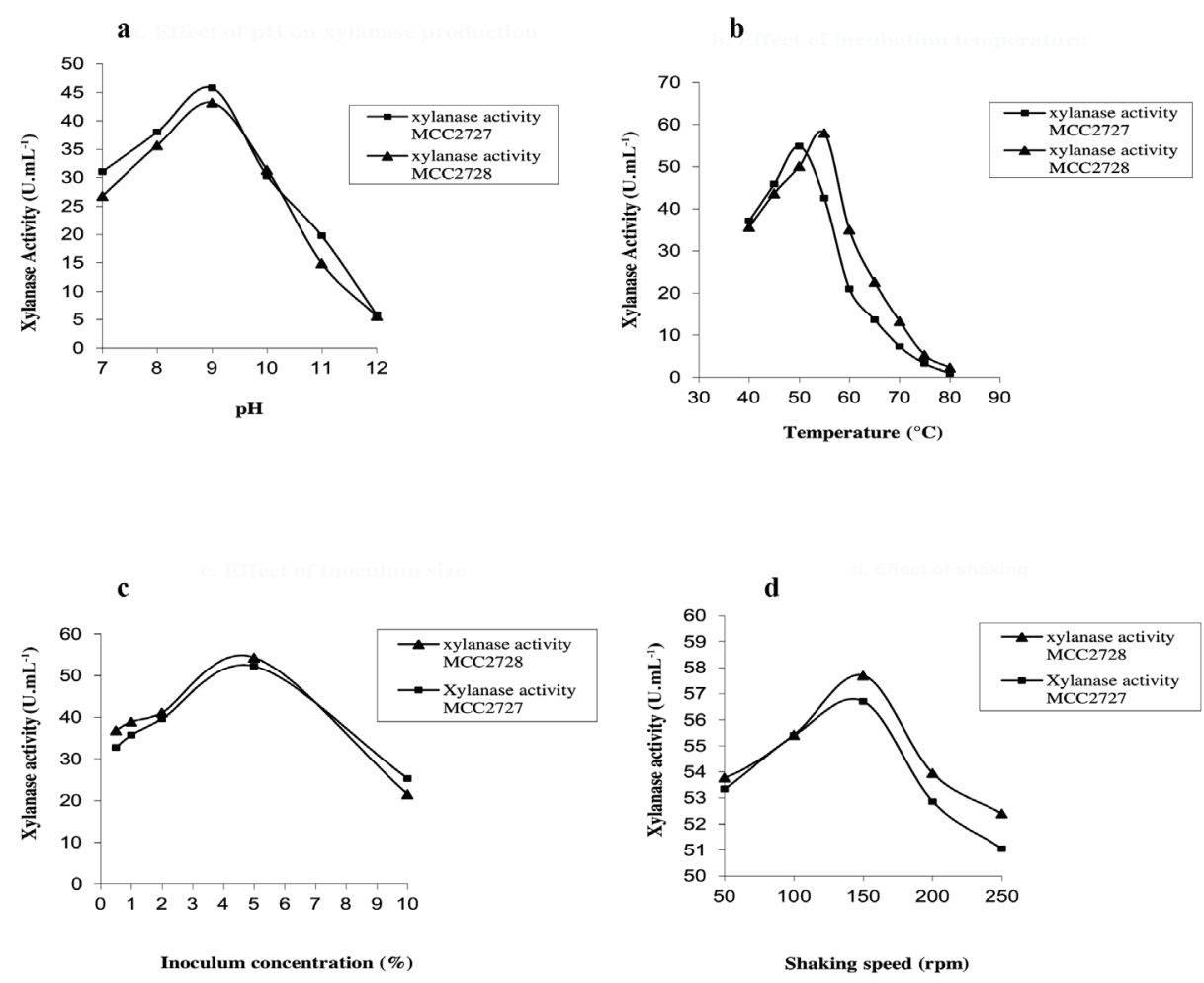

Figure 4. Optimization of growth parameters. a) Effect of $\mathrm{pH}$ on xylanase production. b) Effect of incubation temperature. c) Effect of inoculum size. d) Effect of shaking.

samples produced the maximum number of xylanase producing bacteria. It can be argued that soil is the best and common source for isolating various industrially important organisms. Moreover, the biological system of forest soil includes organic constituents and minerals which makes it a high microbial diversity hub (20). The studies on soil profiles indicate both fungal and

Table 4. Optimization of the best carbon source.

\begin{tabular}{lcc}
\hline & \multicolumn{2}{c}{ Xylanase Activity $\left(\right.$ IU.mL $\left.\mathbf{m}^{-1}\right)$} \\
\hline Carbon source & $\begin{array}{c}\text { Bacillus } \boldsymbol{s p} . \\
\text { MCC2728 }\end{array}$ & $\begin{array}{c}\text { Bacillus } \boldsymbol{s p} \text {. } \\
\text { MCC2728 }\end{array}$ \\
\hline Glucose & $1 \pm 0.15$ & $0.95 \pm 0.72$ \\
Xylose & $46.56 \pm 0.82$ & $36.22 \pm 0.53$ \\
CMC & $1.19 \pm 0.12$ & $1.12 \pm 0.56$ \\
Arabinose & $2.04 \pm 0.09$ & $1.25 \pm 0.56$ \\
Xylan & $37.84 \pm 0.87$ & $44.62 \pm 0.25$ \\
Galactose & $1.88 \pm 0.62$ & $1.50 \pm 0.30$ \\
Sucrose & $1.02 \pm 0.30$ & $1.20 \pm 0.65$ \\
Wheat bran & $78.13 \pm 0.49$ & $79.22 \pm 0.70$ \\
Rice bran & $32.03 \pm 0.50$ & $33.45 \pm 0.42$ \\
Straw & $30.50 \pm 0.32$ & $30.25 \pm 0.54$ \\
Cotton seed meal & $6.65 \pm 0.56$ & $8.55 \pm 0.63$ \\
Gram meal & $0.19 \pm 0.07$ & $1.95 \pm 0.37$ \\
Mannose & $0.59 \pm 0.30$ & $0.62 \pm 0.46$ \\
\hline
\end{tabular}

bacterial diversity is abundant in forest top soils as they are rich in decomposing litter materials (21). The main objective of this study was to isolate xylanolytic bacteria and undoubtedly forest soils are rich in foliage which surely encourages the growth and survival of xylanase producing organisms. Cordeiro et al. (2002) successfully isolated a thermophillic bacterial isolate from local soil (22). Also xylanolytic bacteria like Bacillus cereus (23); new species of Bacillus sp. similar to Bacillus arseniciselanatis DSM 15340 (24) was isolated from soil. Keeping in view, that no single method can reveal all the microorganisms present in a sample, therefore, screening of xylanase producing bacteria was attempted in three different stages. As a part of enrichment technique in the preliminary screening, isolation was performed on wheat bran agar medium. Primary screening on this medium helped to specifically screen potential organisms from a broad range of organisms present in soil. The critical step of primary screening on wheat bran agar medium helped eliminate bulk of unwanted isolates. Nagar et al. (2012) were successful in isolating and screening out 70 xylanolytic bacterial isolates from 14 samples of decaying wood, soil and compost using wheat bran agar medium (25).

Wheat bran is rich in xylan; however the presence of starch and protein will also favor the growth of 
Table 5. Optimization of Nitrogen Source.

\begin{tabular}{lcc}
\hline & \multicolumn{2}{c}{ Xylanase Activity (IU.mL ${ }^{-1}$ ) } \\
\hline Nitrogen source & Bacillus sp. MCC2728 & Bacillus sp. MCC2728 \\
\hline Urea & $12.35 \pm 0.60$ & $10.35 \pm 0.56$ \\
Peptone & $34.50 \pm 0.64$ & $56.25 \pm 0.23$ \\
Beef extract & $30.45 \pm 0.50$ & $26.02 \pm 0.54$ \\
Yeast extract & $60.80 \pm 0.72$ & $83.50 \pm 0.21$ \\
Casein & $3.21 \pm 0.23$ & $2.56 \pm 0.41$ \\
Yeast extract + peptone & $86.05 \pm 0.25$ & $55.01 \pm 0.35$ \\
Tryptone & $23.05 \pm 0.56$ & $19.35 \pm 0.52$ \\
Sodium nitrate & $11.23 \pm 0.42$ & $8.62 \pm 0.46$ \\
Ammonium nitrate & $3.52 \pm 0.28$ & $3.21 \pm 0.55$ \\
Ammonium di hydrogen Phosphate & $13.24 \pm 0.51$ & $12.03 \pm 0.32$ \\
\hline
\end{tabular}

amylase or proteinase producing bacteria along with xylanase producers. Therefore, secondary screening was performed on xylan agar medium with xylan as sole carbon source. This helped to weed out nonxylanolytic bacterial isolates. The identification of xylanase producing bacteria was possible with Congo red assay method.

Twenty four isolates were screened out by this method. However, selection of potent isolates simply on the basis of their zone diameter would be unreliable and biased as some probably high potential enzyme producing bacterial isolates may not produce any extracellular enzyme on solid media (26). Thus, correlation and regression analysis which was initiated to analyze the existence of any relationship between zone diameter and enzyme activity in this study confirmed that there was statistically no significant correlation between the two variables $[\mathrm{r}=0.131, \mathrm{p}(2$ tailed $)=0.551, \mathrm{n}=$ 24]. The zone diameter accounts for only $1.6 \%$ of the variation in enzyme activity and $98.4 \%$ of variation in activity depends on other factors $\left(\mathrm{R}^{2}=0.016\right)$. It can be concluded from regression analysis $(p=0.559)$ that there is no significantly supported relationship between zone diameter and enzyme activity or put simply the zone diameter does not statistically affect xylanase activity. The regression equation can be constructed as follows: Activity $(\mathrm{Y})=12.169+3.743 *$ Zone $(\mathrm{X})$. Also studies by Teather and wood (1982), suggest that clear zone by an organism is not a correct indicator of it being the highest producer (27). Thus, screening should be done using both solid agar as well as liquid medium (28). Therefore, to rule out such biased selection all the selected isolates were grown in liquid xylan medium and xylanase enzyme was quantitatively evaluated. Two isolates ISL-03 $\left(36.61 \pm 3.866 \mathrm{U}^{\left.-\mathrm{mL}^{-1}\right)}\right.$ and ISL$58\left(33.96 \pm 2.059\right.$ U.mL $\left.{ }^{-1}\right)$ were maximum xylanase producing bacterial isolates and were subjected to identification studies.

\subsection{Identification and Phylogenetic Analysis}

The morphological characterization of ISL-03 and ISL58 revealed significant differences between the two isolates. However, both were Gram-positive endospore formers and catalase-positive. These features are in accordance with Bacillus subtilis (29); Bacillus cereus (23) and Bacillus aerophilus KGJ2 (30). One hundred percent sequence homology was observed between $16 \mathrm{~S}$ rRNA gene sequences of both the isolated bacterial strains and with their closest neighbours. Literature survey reveals that although Shivaji et al. (2006) observed 100\% sequence homology between Bacillus aerius, Bacillus aerophilus and Bacillus stratosphericus and also with their closest neighbours, but classified them into different species as he argued that strains exhibiting phenotypic and chemotaxonomic differences amongst themselves and from their related phylogenetic type strains in spite of having $100 \%$ sequence similarity imply that they are different species (31).

The indigenous, potent bacterial isolates designated as Bacillus sp. MCC2727 and Bacillus sp. MCC 2728 are interesting novel bacterial species with xylanolytic properties which can be exploited for their ability to convert biomass and agricultural wastes to industrially important products.

\subsection{Optimization}

Medium $\mathrm{pH}$ greatly influences growth of microorganisms and the transportation of nutrients across the membrane into the cell (32). The studies concerned with optimization of medium $\mathrm{pH}$ showed that both Bacillus sp. MCC2727 and Bacillus sp. MCC2728 produced maximum xylanase activity at $\mathrm{pH}$ 9.0. These 
results are in accordance with that of Staphylococcus sp. (33) and Enterobacter sp. MTCC 5112 (34) which are reported to have produced maximum xylanases at $\mathrm{pH}$ 9.0. Further increase to $\mathrm{pH} 11$ and 12 recorded $70 \%$ decline in xylanase production which might be due to the direct effect of extreme medium $\mathrm{pH}$ on cytoplasmic $\mathrm{pH}$ of microbial cells which in turn may have affected the growth and thus enzyme productivity. xylanase production was observed in a wide range of incubation temperatures but optimum temperature for Bacillus sp. MCC2728 was determined to be $55{ }^{\circ} \mathrm{C}$ and for Bacillus sp. MCC2727, it was $50{ }^{\circ} \mathrm{C}$. The results are in accordance with those of Subramaniyan and Prema (2000) who reported maximum xylanase production by Bacillus sp. at $50^{\circ} \mathrm{C}$ (35). Also, Annamalai et al. (2009) has reported the optimum temperature for another Bacillus sp. to be at $55^{\circ} \mathrm{C}(29)$. So it may be argued that at these optimum temperatures, probably, the physical properties of the bacterial cell membranes might have changed thus influencing the increased extracellular xylanase production. However, negligible xylanase production at $70{ }^{\circ} \mathrm{C}$ and above may be attributed to either reduced solubility of oxygen in the medium at high temperatures or due to denaturation of enzymes (36).

Optimization of inoculum size is important to ensure maximum enzyme production as the initial bacterial count greatly affects the rate of consumption of limited nutrients in the medium. The suitable inoculum size for maximum xylanase production by Bacillus $s p$. MCC2727 and Bacillus sp. MCC2728 was observed to be at $5 \% \mathrm{v} / \mathrm{v}$, which may be due to availability of suitable growth conditions contributed by provision of sufficient amount of nutrients and oxygen supply thereby enhancing xylanase production. Literature survey reveals varied optimum inoculum sizes for different bacterial isolates. Kumar et al. 2014 (37) reported 1\% $\mathrm{v} / \mathrm{v}$ as the best inoculum size for Bacillus pumilus VLK-1 while $1-2 \% \mathrm{v} / \mathrm{v}$ was reported to be optimum for Bacillus $s p$. isolated by Sanghi et al. 2009 (38) and Nagar et al. $2012(25)$. High inoculum volumes $(10 \% \mathrm{v} / \mathrm{v})$ proved to be unfavorable probably due to tremendous increase in microbial growth resulting in increased viscosity of the medium (39). Also, large inoculum volumes may result in excessive imbalance in nutrient contents in the medium. Successful process development on a small scale largely depends on shaking conditions of the production medium. Studies on effect of shaking in maximizing the xylanase production revealed increased xylanase production by both the isolates compared to static conditions. This can be explained by the fact that agitation of medium helps adequate mixing of medium components and also proper heat and mass transfer. The effect of shaking speeds on xylanase production showed that maximum xylanase titer was obtained at $150 \mathrm{rpm}$ by both Bacillus sp. MCC2727 and Bacillus sp. MCC2728. It can be argued that this optimum shaking speed probably ensured adequate amounts of dissolved oxygen and helped maintain homogenous physical and chemical conditions in the culture medium (40). Medium formulation containing appropriate carbon and nitrogen source is one of the most crucial factors for any process development. Among the wide range of carbon sources tested, the complex lignocellulosic material; wheat bran proved to be the best carbon source for both the bacterial isolates probably because it is rich in both xylan and proteins which can be suitably used as carbon and energy sources (41). Wheat bran consisting of $20-30 \%$ xylan is an abundantly available agriculture waste residue strongly suggesting it to be a suitable candidate for use as an inexpensive substrate for xylanase production at industrial scale. These findings are in accordance with the reports of Bajaj et al. 2010 (42); Geetha and Gunasekaran, 2010 (43) and Gupta and Kar, 2010 (44). The findings on optimization of nitrogen sources suggests that organic nitrogen sources are more efficient in xylanase induction probably due to the fact that they contain most of the required essential amino acids for proper growth and xylanase production. Among the tested sources, a blend of yeast extract and peptone facilitated maximum xylanase production in Bacillus $s p$. MCC2728 while yeast extract as the sole nitrogen source was capable of producing optimum xylanase levels in Bacillus sp. MCC2727. These findings are in line with those of Giridhar and Chandra, 2010 (45) who recorded maximum xylanase levels with yeast extract and tryptone. The observation of yeast extract as the best nitrogen source for Bacillus sp. MCC2727 coincides with the reports of Kumar et al. 2014 (37) and Subramaniyan et al. 2001(11). Finally it can be concluded that the two novel bacterial isolates which have been isolated from the forest regions of BhilaiDurg of Chhattisgarh state; India are potent enough to be used in the industrial production of various value added products. Moreover, the ability of these isolates to utilize inexpensive waste agricultural materials for xylanase production can be exploited for both biodegradation and other biotechnological purposes, keeping in view of the huge annual turnover of forest biomass and agriculture waste residues in this region.

\section{Acknowledgment}

The authors thank Dr. Shubha Thakur for her help and assistance in statistical analysis of the data. 


\section{References}

1. Kumar SS, Panday DD, Naik GR. Purification and molecular characterization of low molecular weight cellulase-free xylanase from thermoalkalophilic Bacillus sp JB99. World J Sci Tech. 2011;1(2):9-16. doi: 10.1007/s12010-010-8980-6.

2. Li k, Azadi p, Collins R, Tolan J, Kim JS, Eriksson KL. Relationships between activities of xylanases and xylan structure. Enzyme Microb Tech. 2000;27:89-94. doi: 10.1016/ s0141-0229(00)00190-3.

3. Saha BC. Hemicellulose Bioconversion: A Review. $J$ Ind Microbiol Biotechnol. 2003;30:279-291. doi: 10.1007/s10295003-0049-x.

4. Collins T, Gerday C, Feller G. Xylanases, xylanases families and extremophilic xylanases. FEMS Microbiol Rev. 2005; 29:3-23. doi: 10.1016/j.femsre.2004.06.005.

5. Abo-State MAM, Ghaly MF, Abdellah EM. Production of cellulases and xylanase by thermophilic and alkalophilic bacterial strains isolated from agricultural wastes. World Appl Sci J. 2013;22(11):1603-1612. doi: 10.1007/bf00170939.

6. Kulkarni N, Shendye A, Rao M. Molecular and biotechnological aspects of xylanases. FEMS Microbiol Rev. 1999;23:411-456. doi: 10.1111/j.1574-6976.1999.tb00407.x.

7. Ragauskas AJ, Nagy M, Kim DH, Eckert CA, Hallett JP, Liotta CL. From wood to fuels: Integrating biofuels and pulp production. Ind Biotechnol. 2006;2:55-65. doi: 10.1089/ind.2006.2.55.

8. Scheller HV, Ulvskov P. Hemicelluloses. Annu Rev Plant Biol. 2010;61:263-289. doi: 10.1146/annurevarplant-042809-112315.

9. Subramaniyan S, Prema P. Biotechnology of microbial xylanases: Enzymology, molecular biology and application. Crit Rev Biotechnol. 2002;22:33-46. doi: 10.1080/07388550290789450.

10. Subramaniyan S, Prema P, Ramakrishna SV. Isolation and Screening of Alkaline thermostable Xylanases. J Basic Microbiol. 1997;37:431-437. doi: 10.1002/jobm.3620370610.

11. Subramaniyan S, Sandhya GS, Prema P. Control of xylanase production without protease activity in Bacillus sp by selection of nitrogen source. Biotechnol Lett. 2001;23:369-371. doi: 10.1023/a:1005663704321.

12. Kumar D, Verma R, Sharma P, Rana A, Sharma R, Prakash C. Production and partial purification of xylanase from a new thermophilic isolate. Biol Forum. 2010;2(2):83-87. doi: 10.1007/s13205011-0069-5.

13. Anuradha P, Vijayalakshmi K, Prassana ND, Sridevi K. Production and properties of alkaline xylanases from Bacillus sp isolated from sugar cane fields. Curr Sci. 2007;92:12831286. doi: 10.3923/pjbs.2004.777-781.14. Bailey MJ, Biely P, Poutanen K. Interlaboratory testing of methods for assay of xylanase activity. J Biotechnol. 1992;23:257-270. doi: 10.1016/0168-1656(92)90074-j.

15. Miller GL. Use of dinitrosalicylic acid reagent for the determination of reducing sugars. Anal Chem. 1959;31:538542. doi: 10.1021/ac60147a030.

16. Lowry OH, Rosebrough NJ, Farr AL, Randall RJ. Protein measured with the Folin phenol reagent. J Biol Chem. 1951;193:265-275. doi: 10.1016/0003-2697(79)90222-7.

17. Saitou N, Nei M. The neighbor-joining method: A new method for reconstructing phylogenetic trees. Mol Biol Evol. 1987;4:406-425. doi: 10.1093/oxfordjournals.molbev.a040527.

18. Kimura M. A simple method for estimating evolutionary rate of base substitutions through comparative studies of nucleotide sequences. J Mol Evol. 1980;16:111-120. doi: 10.1007/ bf01731581.

19. Felsenstein J. Confidence limits on phylogenies: An approach using the bootstrap. Evolution. 1985;39:783-791. doi: $10.2307 / 2408678$.

20. Agnelli A, Ascher J, Corti G, Ceccherini MT, Nannipieri, Pietramellara G. Distribution of microbial communities in a forest soil profile investigated by microbial biomass, soil respiration and DGGE of total and extracellular DNA. Soil Biol Biochem. 2004;36:859-868. doi: 10.1016/j. soilbio.2004.02.004.

21. Baldrian P, Kolarık M, Stursova M, Kopecky J, Valaskova $\mathrm{V}$, Vetrovsky T. Active and total microbial communities in forest soil are largely different and highly stratified during decomposition. ISME J. 2012;6:248-258. doi: 10.1038/ ismej-2011.95.

22. Cordeiro CAM, Martins MLL, Luciano AB and Silva RF. Production and properties of xylanase from thermophilic Bacillus sp. Braz Arch Biol Technol. 2002;45:413-418. doi: 10.1590/s1516-89132002000600002.

23. Roy N, Habib RM. Isolation and characterization of Xylanase producing strain of Bacillus cereus from soil. Iranian $J$ Microbiol. 2009;1(2):49-53. doi: 10.15373/2249555x/ may2014/5.

24. Kamble RD, Jadhav AR. Isolation, purification and characterization of xylanase produced by a new species of Bacillus in solid state fermentation. Int J Microbiol. 2012;18. doi:10.1155/2012/683193.

25. Nagar S, Mittal A, Gupta VK. A cost effective method for screening and isolation of xylan degrading bacteria using agro waste material. Asian J Biol Sci. 2012;5(8):384-394. doi: $10.3923 /$ ajbs.2012.384.394.

26. Tseng YH, Fang TJ, Tseng SM. Isolation and characterization of a phytase from Penicillium simplicissimum. Folia Microbiol. 2000;45:121-127. doi: 10.1007/bf02817409.

27. Teather RM, Wood PJ. Use of congo red polysaccharide interactions in enumeration and characterization of cellulolytic bacteria from bovine rumen. Appl Environ Microbiol. 1982;43:777-780. doi: 10.1111/15746941.12318.

28. Sridevi B, Charya MAS. Isolation, identification and screening of potential cellulase-free xylanase producing fungi. Afr J Biotechnol. 2011;10(22):4624-4630. doi: 10.5897/ajb11.2356.

29. Annamalai N, Thavasi R, Jayalakshmi S, Balasubramanian T. Thermostable and alkaline tolerant xylanase production by Bacillus subtilis isolated from marine environment. Indian J Biotechnol. 2009;8:291-297. doi: 10.1007/s12088011-0160-z.

30. Gowdhaman D, Jeyalakshmi G, Sugumaran K, Subramanian NS, Santhosh RS, Ponnusami V. Optimization of the xylanase production with the newly isolated Bacillus aerophilusKGJ2. Turk J Biochem. 2014;39(1)70-77. doi: 10.5505/tjb.2014.92300.

31. Shivaji S, Chaturvedi P, Suresh K, Reddy GSN, Rajaratnam P, Wainwright $M$. Bacillus aerius sp nov., Bacillus aerophilus sp nov., Bacillus stratosphericus sp nov. and Bacillus altitudinis sp nov., isolated from cryogenic tubes used for collecting air samples from high altitudes. Int $J$ Syst Evol Microbiol. 2006;56:1465-1473. doi: 10.1099/ ijs.0.64029-0. 
32. Subramaniyan S, Sandhya GS, Prema P. Control of xylanase production without protease activity in Bacillus sp by selection of nitrogen source. Biotechnol Lett. 2001;23:369-371. doi: 10.1023/a:1005663704321.

33. Gupta S, Bhushan B, Hoondal GS. Isolation, purification and characterization of xylanase from Staphylococcus sp SG-13 and its application in biobleaching of kraft pulp. J Appl Microbiol. 2000;88:325-334. doi: 10.1046/j.1365-2672.2000.00974.x.

34. Khandeparkar R, Bhosle NB. Isolation, purification and characterization of the xylanase produced by Arthrobacter sp MTCC5241 when grown in solid-state fermentation. Enzyme Micro Tech. 2006;39:732-742. doi: 10.1016/j. enzmictec.2005.12.008.

35. Subramaniyan S, Prema P. Cellulase-free xylanases from Bacillus and other microorganisms. FEMS Microbiol Lett. 2000;183:1-7.10.1111/j.1574-6968.2000.tb08925.x.

36. Masomian M, Rahman RNZRA, Salleh A, Basri M. A unique thermostable and organic solvent tolerant lipase from newly isolated Aneurinibacillus thermoaerophilus strain HZ: Physical factor studies. World J Microbiol Biotechnol. 2010;26(9):169316701. doi: 10.1007/s11274-010-0347-1.

37. Kumar L, Kumar D, Nagar S, Gupta R, Garg N, Kuhad RC. Modulation of xylanase production from alkaliphilic Bacillus pumilus VLK-1 through process optimization and temperature shift operation. 3 Biotech. 2014;4:345-356. doi: 10.1007/ s13205-013-0160-2.

38. Sanghi A, Garg N, Kuhar K, Kuhad RC, Gupta VK. Enhanced production of cellulase-free xylanase by alkalophilic Bacillus subtilis ASH and its application in biobleaching of kraft pulp. BioResources. 2009;4:1109-1129. doi: 10.1590/s151783822010000200029.

39. Dinarvand M, Arif AB, Moeini H, Masomian M, Mousavi
SS, Nahavandi R. Effect of extrinsic and intrinsic parameters on inulinase production by Aspergillus niger ATCC 20611. Electron J Biotechnol. 2012;15(4):1-9. doi: 10.2225/vol15issue4-fulltext-9.

40. Purwanto LA, Ibrahim D, Sudrajat H. Effect of agitation speed on morphological changes in Aspergillus niger hyphae during production of tannase. World J Chem. 2009;4:34-38. doi: 10.4331/wjbc.v6.i3.265.

41. Adolph S, Müller SR, Siedenberg D, Jager K, Lehmann H, Schüerl K. Cultivation of Aspergillus awamorii on wheat bran: Ultrastructural description of growth and localization of xylanase by immunogold labeling. J Biotechnol. 1996;46:221234. doi: 10.1016/0168-1656(95)00198-0.

42. Bajaj BK, Pangotra H, Wani MA, Sharma P, Sharma A. Partial purification and characterization of a highly thermostable and $\mathrm{pH}$ stable endoglucanase from a newly isolated Bacillus strain M-9. Indian J Chem Technol. 2009;16:382-387. doi: $10.5580 / 1$ eda.

43. Geetha K, Gunasekaran P. Optimization of nutrient medium containing agricultural waste for xylanase production by Bacillus pumilus B20. Biotechnol Bioprocess Eng. 2010;15:882889. doi: 10.1007/s12257-009-3094-0.

44. Gupta U, Kar R. Xylanase Production by a thermo-tolerant Bacillus Species under Solid-state and Submerged Fermentation. Braz Arch Biol Technol. 2010;52(6):1363-1371. doi: 10.1590/ s1516-89132009000600007.

45. Giridhar PV, Chandra TS. Production of novel halo-alkalithermo-stable xylanase by a newly isolated moderately halophilic and alkali-tolerant Gracilibacillus sp. TSCPVG. Process Biochem. 2010;45:1730-1737. doi: 10.1016/j. probio.2010.07.012. 